\title{
Youth who neither study nor work: Mental health, education and employment
}

\author{
Corina Benjet, PhD, , (1) Dewi Hernández-Montoya, MD MS,(2) Guilherme Borges, DSc, ${ }^{(1)}$ Enrique Méndez, MS, ${ }^{(3)}$ \\ María Elena Medina-Mora, PhD, (1) Sergio Aguilar-Gaxiola, MD PhD.(4)
}

Benjet C, Hernández-Montoya D, Borges G, Méndez E, Medina-Mora ME, Aguilar-Gaxiola S. Youth who neither study nor work: Mental health, education and employment. Salud Publica Mex 2012;54:410-4I7.

\begin{abstract}
Objective. Limited educational and job opportunities for youth has led to a phenomenon termed NEET (not in education, employment or training). The objective is to estimate the prevalence of psychiatric disorders, substance use and suicidal behavior in youth classified as NEET and to compare with those who study only, work only or do both. Material and Methods. 3005 12-to- 17 year-olds in Mexico City were evaluated in 2005 with the Composite International Diagnostic Interview. Descriptive and logistic regression analyses considered the multistage weighted sample design. Results. NEET youth as well as those who work only or study and work simultaneously have greater odds of psychiatric disorder, substance use and suicidal behavior compared to those who study exclusively even after controlling for social disadvantage. Conclusion. Vulnerability is not circumscribed to NEET adolescents, but to all teens who are not exclusive students. Supporting youth to continue studying exclusively may buffer negative mental health outcomes.
\end{abstract}

Key Words: Student dropout; employment; adolescent psychiatry; substance-related disorders; suicide; Mexico
Benjet C, Hernández-Montoya D, Borges G, Méndez E, Medina-Mora ME, Aguilar-Gaxiola S.

Jóvenes que ni estudian ni trabajan:

salud mental, educación y empleo.

Salud Publica Mex 2012;54:410-4I7.

\section{Resumen}

Objetivo. Oportunidades educativas y laborales limitadas para los jóvenes han dado lugar al fenómeno de adolescentes que no estudian ni trabajan (NINls). El objetivo es estimar la prevalencia de trastornos psiquiátricos, consumo de sustancias y conducta suicida en adolescentes NINIs y compararlos con adolescentes que estudian exclusivamente, trabajan exclusivamente y quienes estudian y trabajan. Material y métodos. 3005 adolescentes entre 12 y 17 años de edad fueron evaluados en 2005 con la Entrevista Internacional Psiquiátrica Compuesta en una encuesta multietápica, estraficada y representativa del Distrito Federal y municipios conurbados. Resultados. Los NINIs, quienes trabajan, y quienes estudian y trabajan tienen mayor riesgo de trastornos psiquiátricos, consumo de sustancias y conducta suicida en comparación con aquellos que estudian exclusivamente. Conclusión. La vulnerabilidad no se circunscribe a los NINIs sino a todos los que no son estudiantes exclusivamente. Apoyar a los jóvenes para que estudien podría beneficiar su salud mental.

Palabras clave: abandono de los estudiantes; empleo; psiquiatría del adolescente; trastornos relacionados con sustancias; suicidio; México

(I) Instituto Nacional de Psiquiatría Ramón de la Fuente. México.

(2) Facultad de Medicina, Universidad Nacional Autónoma de México. México.

(3) Instituto de Investigaciones en Matemáticas Aplicadas y en Sistemas, Universidad Nacional Autónoma de México. México.

(4) Center for Reducing Health Disparities, Universidad de California. Davis, EUA.

Received on: October 7, 20II • Accepted on: February I, 2012

Corresponding author: Dra. Corina Benjet. Dirección de Investigaciones Epidemiológicas y Psicosociales, Instituto Nacional de Psiquiatría Ramón de la Fuente. Calzada México-Xochimilco I0I, Col. San Lorenzo Huipulco, I4370 México DF, México. E-mail: cbenjet@imp.edu.mx 
Social inequality and lack of educational and employment opportunities for youth in many societies, and in particular in developing countries like Mexico, has led to a phenomenon of adolescents who are disengaged from major social institutions having abandoned their education, but unable to insert themselves into the labor force. These youth were first referred to as NEET (not in education, employment or training) as a British government classification. In Britain an estimated $9.4 \%$ of those between 16 and 18 were classified as NEET in 2007. ${ }^{1}$ By 2010, NEET youth in 26 OECD countries reached $12.5 \%$ of $15-24$ year olds. ${ }^{2}$ Percentages are higher in the developing world where social inequality is greater. In Mexico, the National Institute of Statistics, Geography and Informatics estimated two million adolescents between the ages of 14 and 19 neither study nor work representing $13.4 \%$ of this population ${ }^{3}$, while the Mexican Institute of Youth estimated that $16 \%$ of youth between 15 and 19 and $6 \%$ of youth between 12 and 14 are NEET despite mandatory education up to age $15 .{ }^{4}$

Mental illness is likely to be both a risk factor for becoming NEET as well as a consequence of NEET status. Youth with prior mental illness are likely to terminate school early, especially those with conduct disorder and attention deficit hyperactivity disorder. ${ }^{5}$ Results from the World Health Organization's World Mental Health Surveys suggest that in high income countries early mental disorders are associated with early termination of all educational levels whereas in low and middle income countries early mental disorders are associated with early termination mainly of secondary education presumably because in lower income countries other factors such as economic necessity also contribute to early school termination. ${ }^{6}$ Prior mental disorders are also likely to impede the transition into the labor force due to employment restrictions. ${ }^{7}$

On the other hand the social exclusion of NEET status, the lack of structured time and supervision, and the failure to meet social expectations might lead to feelings of hopelessness, life dissatisfaction, substance use, behavioral problems, and other mental health outcomes such as suicidality. A study in New Zealand of unemployment following school leaving found that exposure to unemployment was associated with increased risks of suicidal thoughts, crime and substance abuse, but not depression after accounting for prior psychosocial adjustment and confounding factors. ${ }^{8}$

There has been increasing attention given to this population of disengaged youth. International organizations have warned that these youth may face persistent scarring for as many as 20 years in terms of long-term unemployment and future pay differentials. ${ }^{2}$ In Mexico, mass media and policy makers have expressed concern that NEETs are particularly vulnerable to recruitment from drug traffickers and organized crime. ${ }^{9}$ However, relatively little is known about these youth around the globe, how they compare to youth engaged in education, employment or both. Therefore the objectives of this study are to estimate the socio-demographic characteristics and the prevalence of psychiatric disorders, substance use and suicidal behavior of adolescents in Mexico City classified as NEET (nini in Spanish), those who work only, those who both work and study, and to compare with adolescents who study only.

\section{Material and Methods}

\section{Participants}

This article presents secondary data analyses from the Mexican Adolescent Mental Health Survey ${ }^{10}$ which was conducted in 2005 and designed to be representative of adolescents in Mexico City. The sample consists of 3005 adolescents aged 12 to 17 selected with a stratified multistage area probability sample design. In all strata, the primary sampling units were census count areas cartographically defined by the National Institute of Statistics, Geography and Informatics. Secondary sampling units were city blocks selected with probability proportional to size. All households within these city block units with adolescents in the age range were selected and one eligible adolescent from each was randomly selected using random number charts. The response rate was $71 \%$ of eligible respondents.

\section{Procedures}

A verbal and written explanation of the study was given to both parents and adolescents, after which a signed informed consent from the parent was obtained as well as the assent of the adolescent. Interviews were conducted in the homes of the participants, all of whom were offered information on local mental health services. The Internal Review Board of the National Institute of Psychiatry approved the recruitment, consent and field procedures.

\section{Measures}

Psychiatric diagnosis, substance use, suicidal behavior, education and employment were evaluated with the fully-structured, computer-assisted, World Mental Health adolescent version of the Composite International Diagnostic Interview (WMH-CIDI-A), the development and validity of which is described elsewhere. ${ }^{11-12}$ Diagnostic classification was based on meeting criteria of the Di- 
agnostic and Statistical Manual of Mental Disorders, Fourth Edition. ${ }^{13}$ The disorders included were: mood disorders (major depressive disorder, bipolar I and II, and dysthymia), anxiety disorders (specific phobia, social phobia, panic disorder, agoraphobia, separation anxiety disorder, generalized anxiety disorder and posttraumatic stress disorder), substance use disorders (alcohol and drug abuse and dependence), and behavioral disorders (oppositional-defiant disorder, conduct disorder, attention deficit/hyperactivity disorder, and intermittent explosive disorder).

A section on substance use asked about use in the previous 12 months of tobacco, alcohol and drugs (marijuana, cocaine, tranquilizers or stimulants used without a medical prescription, heroine, inhalants, and other drugs). A section on suicidal behavior asked about suicidal ideation ("Have you ever seriously thought about committing suicide?"), suicidal plan ("Have you ever made a plan for committing suicide?"), and suicide attempt ("Have you ever attempted suicide?").

In the education and employment sections respondents report whether they currently attend school, highest academic level, whether currently employed, the type of job, and number of hours worked per week. Employment includes both remunerated and non-remunerated work such as in a family business and formal and informal employment, but does not include volunteerism. Education includes vocational/ technical training. The classification of education/employment status reflects the specific point in time of the interview.

\section{Analysis}

The data were weighted to adjust for differential probabilities of non-response and post-stratification was performed to the age and sex distribution of the Mexico City adolescent population. Weighted proportions are presented for four groups: those who neither study nor work, those who study and work, those who work only, and those who study only. As a result of this complex sample design and weighting, estimates of standard errors for proportions were obtained by the Taylor series linearization method using SUDAAN software. * To estimate the association of educational/ labor force involvement with mental health outcomes (psychiatric diagnosis, substance use and suicidal behavior) a logistic regression analysis was performed

\footnotetext{
* Research Triangle Institute (RTI). Sudaan Release 8.0.1. North Carolina: Research Triangle Institute, 2002.
}

for each mental health outcome controlling for age, sex, socioeconomic status, living with both parents, being married and having children. Estimates of standard errors of Odds Ratios (ORs) from logistic regression coefficients were also obtained by SUDAAN, and 95\% Confidence Intervals (CI) have been adjusted to design effects. Multivariate tests are based on Wald $\chi^{2}$ tests computed from design-adjusted coefficient variancecovariance matrices.

\section{Results}

While three-fourths of teens are students exclusively, $16 \%$ classify as NEET, almost $7 \%$ study and work simultaneously and less than 3\% work exclusively (table I). Of working youth, those who also attend school work an average 17 hours per week while those who do not report an average of 33 hours per week. Those who work and study began to work at age 12.9 while those who only work began at age 13.5. The most frequent occupations are sales, elementary services, and unskilled labor such as hand packing and odd-jobs.

Table I shows the socio-demographic characteristics of the sample. Adolescents classified as NEET are older, have lower family income, lower parental education and are less likely to live with both parents than those who study exclusively. They are also more likely to be married and have children. Youth who work only and youth who both work and study have similar sociodemographic characteristics to the NEET with the exception that those who work and study simultaneously are not likely to be married or have children.

NEETs and working adolescents have a greater prevalence of psychiatric disorders, substance use and suicidal behavior in comparison to students (table II). Because NEETs and working teens are more socially disadvantaged in terms of family income and education, family disintegration and having adult responsibilities such as marriage and children, these variables were controlled for in the analyses to evaluate the association of educational and employment status with psychopathology.

Table III shows the association of educational and employment status with psychiatric disorder, above and beyond the effect of social disadvantage. NEETs have greater odds of mood, substance, behavioral, any disorder and serious disorders when compared to fulltime students with odds ratios ranging from 1.7 to 4.4. They do not have greater odds for anxiety disorders. Similarly those who both study and work have greater odds than those who study exclusively for all disorders excepting anxiety disorders, with odds ratios ranging from 1.9 to 4.2 . Youth who work exclusively have greater 
Table I

Socio-demographic characteristics by educational and employment status, MeXico City 2005

\begin{tabular}{|c|c|c|c|c|}
\hline & $\begin{array}{c}\text { Neither study nor work } \\
n=485 \\
\text { I6.I (0.84) } \\
\% \text { (SE) }\end{array}$ & $\begin{array}{l}\text { Work only } \\
n=8 I \\
2.7(0.4) \\
\%(S E)\end{array}$ & $\begin{array}{l}\text { Study and work } \\
n=208 \\
6.9(0.5) \\
\%(S E)\end{array}$ & $\begin{array}{c}\text { Study only } \\
n=2231 \\
74.3(0.9) \\
\% \text { (SE) }\end{array}$ \\
\hline Mean age & $15.7(0.1)$ & $16.2(0.1)$ & I5.I (0.I) & I4.I (0.I) \\
\hline$\%$ Male & $51.0(3.1)$ & $50.3(7.2)$ & $58.8(4.1)$ & $48.8(1.0)$ \\
\hline$\%$ Lives with both parents & $57.4(3.5)$ & $57.8(5.7)$ & $69.3(3.5)$ & $67.3(0.7)$ \\
\hline \multicolumn{5}{|l|}{ Parental level of education } \\
\hline$\%$ six or less years of education & $4 I .4(2.2)$ & $41.9(6.3)$ & $24.2(2.6)$ & $22.3(0.9)$ \\
\hline$\% 7-9$ years of education & $34.9(2.7)$ & $32.6(6.9)$ & $45.9(4.9)$ & $38.1(1.5)$ \\
\hline$\% 10-12$ years of education & I5.3 (2.4) & I5.5 (5.4) & $22.8(4.2)$ & $24.5(0.8)$ \\
\hline$\%$ Any university education & $8.5(1.6)$ & $10.0(3.2)$ & $7.1(2.0)$ & $15.0(0.7)$ \\
\hline \multicolumn{5}{|l|}{ Parental income } \\
\hline Ist quartile (under) & $21.8(2.3)$ & I8.0 (4.4) & $16.0(3.4)$ & $16.8(0.8)$ \\
\hline 2nd quartile & $58.6(3.1)$ & $56.9(6.2)$ & $64.3(3.7)$ & $55.4(\mathrm{I} . \mathrm{I})$ \\
\hline $3 r d$ quartile & I5.4 (I.6) & $18.9(5.5)$ & $15.6(2.9)$ & $21.3(0.8)$ \\
\hline 4th quartile (above) & $4.3(1.0)$ & $6.2(3.7)$ & $4.2(1.2)$ & $6.5(0.6)$ \\
\hline$\%$ Married & $5.6(1.5)$ & $7.5(3.9)$ & $0.0(0.0)$ & $0.3(0.1)$ \\
\hline$\%$ Have children & $8.1(1.7)$ & $8.6(3.0)$ & $0.2(0.2)$ & $0.2(0.1)$ \\
\hline Mean number of hours of work per week & --- & $33.3(5.0)$ & I7.3 (2.0) & --- \\
\hline
\end{tabular}

Table II

\section{Clinical characteristics by educational and employment status, Mexico City 2005}

\begin{tabular}{|c|c|c|c|c|}
\hline & $\begin{array}{c}\text { Neither study nor work } \\
n=485 \\
16.1(0.8) \\
\% \text { (SE) }\end{array}$ & $\begin{array}{c}\text { Work only } \\
n=81 \\
2.7(0.4) \\
\%(S E)\end{array}$ & $\begin{array}{c}\text { Study and work } \\
n=208 \\
6.9(0.5) \\
\%(S E)\end{array}$ & $\begin{array}{c}\text { Study only } \\
n=2231 \\
74.3(0.9) \\
\% \text { (SE) }\end{array}$ \\
\hline$\%$ 12-month mood disorder & I3.3(I.8) & II.3 (3.4) & $10.1(1.6)$ & $5.5(0.5)$ \\
\hline$\%$ I2-month anxiety disorder & $34.3(3.2)$ & $31.4(4.8)$ & $35.5(3.6)$ & $28.2(0.8)$ \\
\hline$\%$ 12-month substance use disorder & $7.1(1.5)$ & $10.4(4.6)$ & $7.0(1.7)$ & $1.9(0.4)$ \\
\hline$\%$ I2-month behavioural disorder & $13.5(1.9)$ & $20.4(5.8)$ & I5.4 (3.I) & $6.5(0.5)$ \\
\hline$\%$ Any I2-month disorder & $5 I . I(2.6)$ & $48.0(5.1)$ & $52.8(3.1)$ & $36.4(1.0)$ \\
\hline \% Any serious I2-month disorder & $15.4(1.6)$ & I6.9 (4.8) & $14.9(2.8)$ & $6.1(0.5)$ \\
\hline$\%$ I2-month alcohol use & $24.4(1.8)$ & $47.2(6.7)$ & $22.6(4.0)$ & II.2(0.7) \\
\hline$\%$ I2-month tobacco use & $19.0(1.8)$ & $33.6(6)$ & II.6 (2.8) & $5.9(0.6)$ \\
\hline$\%$ I2-month drug use & $5.4(1.5)$ & $10.1(5.3)$ & $5.7(1.7)$ & $1.8(0.3)$ \\
\hline$\%$ Any 12 -month substance use & $32.3(2.0)$ & $56.1(6.4)$ & $26.4(4.4)$ & I3.8(0.85) \\
\hline$\%$ I2-month suicidal ideation & $9.6(1.6)$ & $8.7(3.0)$ & $6.1(2.0)$ & $4.5(0.4)$ \\
\hline$\%$ I2-month suicidal plan & $3.7(0.9)$ & $3.3(2.3)$ & $2.2(0.8)$ & $1.4(0.3)$ \\
\hline$\%$ I2-month suicidal attempt & $4.4(I . I)$ & 4.I (2.4) & $3.9(1.8)$ & $1.2(0.3)$ \\
\hline
\end{tabular}


odds than full-time students of substance, behavioral, and serious disorders, odds ratios ranging from 3.1 to 6.1, but not significantly greater odds of mood, anxiety or any disorder.

The association of educational and employment status with substance use above and beyond the contribution of social disadvantage is presented on table IV. NEET youth, youth who work exclusively and youth who work and study all have increased odds of 12month alcohol, tobacco, drugs and any substance use when compared to exclusive students. The odds ratios range from 2.2 , for the odds of tobacco use among those who both work and study to 9.2 for any substance use among those who work only. Overall the highest odds ratios are for adolescents who work exclusively.

Table V shows the association of educational and employment status with suicidal behavior controlling for social disadvantage. NEETs have greater odds for suicidal ideation, plan and attempt, with odds ratios ranging from 1.8 for ideation to 3.6 for attempt. Those who work exclusively do not have significantly higher odds than students for suicidal behavior. Those who both work and study have four times the odds of a suicide attempt, but no increased odds for ideation or plan.

Table III

Association (OdDS RATIO)* OF EDUCATIONAL AND EMPLOYMENT STATUS WITH I2-MONTH PSYCHIATRIC DisoRders, Mexico City 2005

\begin{tabular}{|c|c|c|c|c|c|c|c|c|c|c|c|c|}
\hline & \multicolumn{2}{|c|}{ Mood } & \multicolumn{2}{|c|}{ Anxiety } & \multicolumn{2}{|c|}{ Substance } & \multicolumn{2}{|c|}{ Behavioral } & \multicolumn{2}{|c|}{ Any disorder } & \multicolumn{2}{|c|}{ Any serious disorder } \\
\hline & $O R$ & $(95 \% \mathrm{Cl})$ & $O R$ & $(95 \% \mathrm{Cl})$ & $O R$ & $(95 \% \mathrm{Cl})$ & $O R$ & $(95 \% \mathrm{Cl})$ & $O R$ & $(95 \% \mathrm{Cl})$ & $O R$ & $(95 \% \mathrm{Cl})$ \\
\hline Neither study nor work & 2.7 & $(1.8-4.2)$ & 1.3 & $(0.9-1.8)$ & 4.4 & $(2.6-7.6)$ & 2.1 & $(1.5-2.8)$ & 1.7 & $(1.3-2.3)$ & 2.8 & $(1.9-4.0)$ \\
\hline Work only & 2.2 & $(0.9-5.1)$ & 1.1 & $(0.7-1.8)$ & 6.1 & $(2.0-18)$ & 3.4 & $(1.5-7.8)$ & 1.5 & $(0.9-2.3$ & 3.1 & $(1.5-6.4)$ \\
\hline Study and work & 2.3 & $(1.5-3.5)$ & 1.5 & $(1.0-2.0)$ & 4.2 & $(2.0-8.6)$ & 2.8 & $(1.8-4.4)$ & 1.9 & $(1.5-2.5)$ & 3.0 & $(2.0-4.4)$ \\
\hline Study only & 1.0 & & 1.0 & & 1.0 & & 1.0 & & 1.0 & & 1.0 & \\
\hline & & & & & & $\begin{array}{l}31.3 \\
0001\end{array}$ & & $\begin{array}{l}1.72 \\
0001\end{array}$ & & $\begin{array}{l}31.2 \\
0001\end{array}$ & & $\begin{array}{l}71.6 \\
0001\end{array}$ \\
\hline
\end{tabular}

\footnotetext{
* Results of six separate logistic regression equations, one for each psychiatric outcome, in which each employment/education category is compared to the reference group of adolescents that study only. All equations controlled for age, sex, lives with both parents, parental education and income, being married and having children
}

\section{Table IV}

Association (OdDS RATIO)* Of EDUCATIONAL AND EMPLOYMENT STATUS With I 2-MONTH SUbSTANCE USE, MeXico City 2005

\begin{tabular}{|c|c|c|c|c|c|c|c|c|}
\hline & \multicolumn{2}{|c|}{ Alcohol } & \multicolumn{2}{|c|}{ Tobacco } & \multicolumn{2}{|c|}{ Drugs } & \multicolumn{2}{|c|}{ Any substance } \\
\hline & $O R$ & $(95 \% \mathrm{Cl})$ & $O R$ & $(95 \% \mathrm{Cl})$ & OR & $(95 \% \mathrm{Cl})$ & $O R$ & $(95 \% \mathrm{Cl})$ \\
\hline Neither study nor work & 3.0 & $(2.4-3.9)$ & 3.9 & $(3.0-4.9)$ & 3.5 & $(1.8-6.9)$ & 3.4 & $(2.7-4.3)$ \\
\hline Work only & 8.4 & $(4.9-14.4)$ & 8.2 & $(5.0-13.6)$ & 7.3 & $(2.4-21.9)$ & 9.2 & $(5.5-15.5)$ \\
\hline Study and work & 2.6 & $(1.6-4.3)$ & 2.2 & $(1.2-4.0)$ & 3.2 & $(1.5-6.6)$ & 2.5 & $(1.4-4.2)$ \\
\hline Study only & 1.0 & & 1.0 & & 1.0 & & 1.0 & \\
\hline & & & & & & & & \\
\hline
\end{tabular}

\footnotetext{
* Results of four separate logistic regression equations, one for each substance use outcome, in which each employment/education category is compared to the reference group of adolescents that study only. All equations controlled for age, sex, lives with both parents, parental education and income, being married and having children
} 
Table V

AsSOCIATION (ODDS RATIO)* OF EDUCATIONAL AND EMPLOYMENT STATUS WITH I 2-MONTH SUICIDAL BEHAVIOR, MeXico City 2005

\begin{tabular}{|c|c|c|c|c|c|c|}
\hline & \multicolumn{2}{|c|}{ Ideation } & \multicolumn{2}{|c|}{ Plan } & \multicolumn{2}{|c|}{ Attempt } \\
\hline & $O R$ & $(95 \% \mathrm{Cl})$ & $O R$ & $(95 \% \mathrm{Cl})$ & $O R$ & $(95 \% \mathrm{Cl})$ \\
\hline Neither study nor work & 1.8 & $(I .1-2.8)$ & 2.4 & $(I .4-4.1)$ & 3.6 & $(2-6.4)$ \\
\hline Work only & 1.5 & $(0.6-3.4)$ & 1.9 & $(0.4-8.5)$ & 3.2 & $(0.8-12)$ \\
\hline Study and work & 1.4 & $(0.7-2.8)$ & 1.8 & $(0.7-4.5)$ & 4.1 & $(1.8-9.1)$ \\
\hline Study only & 1.0 & & 1.0 & & 1.0 & \\
\hline
\end{tabular}

* Results of three separate logistic regression equations, one for each suicidal behavior, in which each employment/education category is compared to the reference group of adolescents that study only. All equations controlled for age, sex, lives with both parents, parental education and income, being married and having children

\section{Discussion}

\section{Overall findings}

NEETs have greater risk of psychiatric disorders, substance use and suicidal behavior when compared to adolescents who study exclusively even after controlling for social disadvantage. However, these findings also indicate that working adolescents, regardless of whether they study, are also vulnerable.

\section{Mexican context}

Adolescence is a critical decade when poverty and inequity are often passed to the next generation through varied mechanisms such as poor adolescent girls giving birth to impoverished children, or early school dropout. In Mexico, 43\% of those between 15 and 19 have left school. ${ }^{4}$ The economic crisis has affected disproportionately the young, with the greatest reduction in work force participation in this group. ${ }^{14}$ Understanding their problems and developing strategies to help them grow in health may break the replication of poverty.

Even in a developing country like Mexico, teens dedicated exclusively to studying are the norm, representing $75 \%$ of this Mexico City sample. While nine years of education are compulsory and guaranteed (usually terminating at age 15), many youth leave education at this age either by choice, financial necessity or by inability to secure school entrance which is no longer guaranteed by the state. For youth between 15 and 19 years of age the primary reasons for leaving school are having to work (40.2\%) and not liking to study (38.2\%) while the primary reasons for those between 12 and 14 are not liking to study (57.5\%), parents not wanting them to continue $(27.1 \%)$, feeling that they have concluded their education $(20.4 \%)$, and to a lesser degree because of having to work (10.3\%). ${ }^{4}$

\section{The association of mental health with NEET status}

The association of poor mental health with NEET status above and beyond social disadvantage suggests that mental health may be an important factor in the successful transition from school to work. Disengagement from socializing institutions (education and labor) may be a reflection of prior mental disturbance or may increase the risk of psychopathology either by failing to provide structure and the necessary developmental experiences or by increasing exposure to other disenfranchised or non-normative peers. These findings are consistent with prior work on early school termination and mental health and unemployment and mental health in young adults. $5,6,8,15,16$ While psychiatric disorders impair functioning in attention, affect regulation and impulsivity which might directly impact educational attainment and employment procurement and performance, other structural factors such as discrimination and lack of support services may also play a role in difficulties for mentally ill persons to get a job. ${ }^{17}$ Also ample evidence suggests that violence exposure and stressful life events impact the development of psychiatric disorders. ${ }^{18}$ Most likely the association of poorer mental health with neither studying nor working is a bidirectional relationship, such that those with psychopathology in 
childhood are more likely to terminate school early and less able to transition into employment, and conversely youth who do not work or study are in high risk situations which compromise mental health. Unexpectedly this association did not hold for anxiety disorders. One possible explanation is that $30 \%$ of anxiety disorders in these youth were specific or social phobias ${ }^{10}$ which are less impairing than other anxiety disorders and other non-anxiety disorders ${ }^{19}$ thus accounting for a weaker or null association.

\section{Youth employment}

Evidence in developed countries suggests that while working a few hours may be beneficial to adolescents, employment for more hours is associated with poor school achievement and substance use. ${ }^{20-22}$ These Mexican adolescents work substantially more hours than is considered beneficial. Consistent with findings that adolescent labor increases substance use, the highest odds of substance use, abuse and dependence in this study are for youth who work whereas the highest odds for other psychiatric disorders and suicidal behavior are for NEET youth. The greater substance use of working adolescents has been attributed to contact with older people and greater access and financial resources to buy substances. Also adolescents with heavy substance use may take on longer hours in order to maintain their purchasing ability. ${ }^{22}$ Jobs for unskilled, inexperienced and underage workers tend to be precarious, in hazardous conditions and may expose youth to exploitation thus further compromising their physical and mental health. ${ }^{23-24}$ Especially in developing countries these jobs are more likely to be in the unprotected informal sector and may include working in the streets, selling pirated merchandise, or other illegal activity. In Mexico, where violence due to drug trafficking and the war on drugs has disproportionately affected the young, mass media and some government officials have suggested, though there are no data to support or refute the claim, that NEET youth are the prime targets of exploitation by organized crime. This aside, youth labor in Mexico is often exploitative which may help explain the negative relationship between youth employment and mental health.

\section{Limitations}

The cross-sectional design of this survey precludes interpretations of causality or directionality. Psychopathology may contribute to the likelihood of entering NEET status, may inversely be a consequence of NEET status, or may only be related by some third variable that is a risk factor related to both. While socio-economic disadvantage is related to both NEET status and psychopathology, our findings held even after controlling for this.

An important limitation of this study is the circumscribed objective of determining if NEET youth have greater mental health risk than others. Our findings suggest that they do, and future research of our group will focus on determining the factors that might explain this risk.

This study is also limited by its definition of NEET which classifies youth by what they are not rather than what they are, and which considers NEET status at one specific point in time not taking into account the duration of NEET status or the dynamic nature of employment and education. Longer duration of unemployment has been found to be more detrimental. ${ }^{8}$

\section{Implications}

Despite these limitations, this study has important implications. Adolescents who study exclusively have better mental health, above and beyond their socioeconomic advantage. Vulnerability is not circumscribed to NEETs, but to all who are not exclusive students. Furthermore, getting NEETs jobs may not be the best strategy as teen labor appears to be deleterious to youth development. The jobs that are available to youth without education or experience are likely to put them in high risk situations, compromise their wellbeing and not further their professional development. These findings suggest a need for evaluating the specific conditions of youth labor which contribute to risk.

Conversely, strategies to increase educational opportunities (assuring availability) and support for continuing education exclusively (such as financial support for those who are unable to remain in school without working) may be more beneficial. Education is likely a protective factor in numerous ways such as allowing youth to focus on the developmental demands of adolescence, limiting peer interaction to same age and normative peer groups, keeping youth out of high-risk contexts, providing structure, supervision, and additional resources such as problem-solving abilities, critical thinking, and self esteem to ease the later transition from school to work. The evidence that those with psychiatric conditions are likely to abandon their education earlier, suggests the importance of prevention and intervention for mental health problems during the primary school years.

\section{Acknowledgements}

This work was supported by the National Council on Science and Technology and the Ministry of Education 
[grant No. CONACYT-SEP-SSEDF-2003-CO1-22]. CONACYT [grant No. CB2006-01-60678] funded additional analyses of adversity. The survey was carried out in conjunction with the World Mental Health (WMH) Survey Initiative. We thank the WMH staff for assistance with instrumentation and fieldwork.

Declaration of conflict of interests. The authors declare that they have no conflict of interests.

\section{References}

I. UK Department for Education. DCSF: NEET Statistics Quartely Brief 2008. [accessed 2010 October 12] Available at: http://www.dcsf.gov.uk/ rsgateway/DB/STA/t00075l/index.shtml.

2. OECD. Off to a good start? Jobs for Youth. 2010. [accessed 201 I June

I] Available at: http://www.oecd.org/document/3I/0,3746,en_2649_37457 46328479 I I I 37457,00.html.

3. Instituto Nacional de Estadisica Geografia e Informatica. Encuesta Nacional de Ocupacion y Empleo 2009. [accessed 2010 October 17] Available at: http://www.inegi.org.mx/prod_serv/contenidos/espanol/bvinegi/productos/encuestas/hogares/enoe/enoe2009/ENOE_2009.pdf. 4. Instituto Mexicano de la Juventud. Jovenes Mexicanos: Encuesta Nacional de Juventud 2005. [accessed 2010 October 12]. Available at: http:// cendoc.imjuventud.gob.mx/investigacion/docs/ENJ2005-Tomol.swf. 5. Breslau J, Miller E, Chung WJJ, Schweitzer JB. Childhood and adolescent onset psychiatric disorders, substance use, and failure to graduate high school on time. J Psychiatr Res 201 I;45:295-301.

6. Lee S, Tsang A, Breslau J, Aguilar-Gaxiola S, Angermeyer M, Borges G et al. Mental disorders and termination of education in high-income and low-and middle-income countries: epidemiological study. $\mathrm{Br} J$ Psychiatry 2009; |94:4||-4I7.

7. Waghorn G, Chant D. Labor force activity by people with depression and anxiety disorders: a population-level second-order analysis. Acta Psychiatr Scand 2005; I 12:4 | 5-424.

8. Fergusson DM, John Horwood L, Woodward LJ. Unemployment and psychosocial adjustment in young adults: causation or selection? Soc Sci Med 200I;53:305-320.

9. BBC Mundo. "Ninis" ponen en jaque a México. [accessed 2010 October 12]. Available at: http://www.bbc.co.uk/mundo/america_ latina/2010/0I//0012I_23/4_mexico_ninis_jrg.shtml.

I0. Benjet C, Borges G, Medina-Mora ME, Zambrano J, Aguilar-Gaxiola $S$. Youth mental health in a populous city of the developing world: results from the Mexican Adolescent Mental Health Survey. J Child Psychol Psychiatry 2009;50:386-395.

II. Kessler RC, Avenevoli S, Green J, Gruber MJ, Guyer M, He Y et al. National comorbidity survey replication adolescent supplement (NCS-A): III. Concordance of DSM-IV/CIDI diagnoses with clinical reassessments. J Am Acad Child Adolesc Psychiatry 2009;48:386-399.

12. Merikangas KR, Avenevoli S, Costello EJ, Koretz D, Kessler RC. The National Comorbidity Survey Adolescent Supplement (NCS-A): I. Background and Measures. J Am Acad Child Adolesc Psychiatry 2009;48:367-379.

13. American Psychiatric Association. Diagnostic and Statistical Manual of Mental disorders (DSM- IV). Washington, DC: APA, 1994

14. Prado A. Los retos para el empleo y la cohesión social de los jovenes en el contexto economico y social regional. [accessed 2012 January 16] Available at: http://www.eclac.cl/noticias/paginas/I/3950I/ForoCohesionSocialLimaSintesis.pdf

I5. Isohanni I, Jones PB, Jarvelin MR, Nieminen P, Rantakallio P, Jokelainen J, et al. Educational consequences of mental disorders treated in hospital. A 31 -year follow-up of the northern Finland 1966 birth cohort. Psychol Med 200I;31:339-349.

16. Waghorn G, Chant D, Lloyd C, Harris MG. Earning and learning among Australian community residents with psychiatric disorders. Psychiatry Res 2011;186:109-116.

17. Cook JA. Employment barriers for persons with psychiatric disabilities: Update of a report for the President's Commission. Psychiatr Serv 2006;57:139|-1405.

I8. Benjet C, Borges G, Medina-Mora ME. Chronic childhood adversity and onset of psychopathology during three life stages: childhood, adolescence and adulthood. J Psychiatr Res 20 10;44:732-740.

19. Merikangas KR, He JP, Burstein M, Swanson SA, Avenevoli S, Cui L et al. Lifetime prevalence of mental disorders in U.S. adolescents: Results from the National Comorbidity Study-Adolescent Supplement (NCS-A). J Am Acad Child Adolesc Psychiatry 2010;49:975-1086.

20. Paschall MJ, Flewelling RL, Russell T. Why is work intensity associated with heavy alcohol use among adolescents? J Adolesc Health 2004;34:79-87. 21. Sabia JJ. School-year employment and academic performance of young adolescents. Econ Edu Rev 2009;28:268-276.

22. Wu L, Schlenger W, Galvin D. The relationship between employment and substance use among students aged 12 to 17. J Adolesc Health 2003;32:5-15.

23. Benjet C. Childhood adversities of populations living in low-income countries: prevalence, characteristics, and mental health consequences. Curr Opin Psychiatry 2010;23:356-362.

24. Pinzon-Rondon AM, Koblinsky SA, Hofferth SL, Pinzon-Florez CE, Briceño L. Work-related injuries among child street-laborers in Latin America: prevalence and predictors. Pan Am J Public Health 2009;26:235-243. 